\title{
Práticas em módulos didáticos de Hidráulicas
}

\author{
Victor Luis De Toledo Poldi (EM), Michele dos Santos Lopes (PG), Lubienska C. L. J. Ribeiro (PQ)
}

\section{Resumo}

Encantar o aluno e fazer da sala de aula um lugar atraente e de troca de conhecimento está se tornando algo difícil nos dias de hoje. Com o avanço das tecnologias os alunos acham que não precisam mais das explicações dos professores, pois tudo está disponível em meio eletrônico, mas isso vem trazendo grandes frustrações de ambas as partes. Atualmente vários estudos estão voltados para a relação entre aluno, professor, ensino e aprendizagem.

Palavras Chave: monitoramento, saneamento, hidráulica.

\section{Introdução}

O projeto tem como objetivos analisar contextos ligados a hidráulica. Várias foram as práticas realizadas no laboratório de hidráulica. Os temas trabalhados foram: Equação do Escoamento, Equação da Continuidade, Bombas, Energia de Pressão, Energia Cinética e número de Reynolds.

O significado etimológico da palavra hidráulica é "condução de água" (do grego: hydor, água e aulos, tubo, condução). Entretanto, atualmente, empresta-se ao termo "Hidráulica" um significado muito mais lato: é o estudo do comportamento da água e de outros líquidos, quer em repouso, quer em movimento (1).

\section{Resultados e Discussão}

Um dos casos mais marcantes das visitas feitas nas práticas de hidráulica foi à abertura das discussões sobre os recursos hídricos que sofrem desperdício e escassez em várias partes do mundo. $E$ com isso foi possível realizar as práticas enfocando alguns temas da hidráulica que serão descritas.

Equação do Escoamento - na hidrodinâmica, a vazão, consiste na quantidade de fluido que passa por unidade de tempo em um determinado local. Se houver um fluido escoando por uma tubulação, a vazão se mantém constante em toda a tubulação. Porém, se o fluido passa pelo canal com algum objeto haverá uma variação na velocidade de escoamento do fluido.

Equação da continuidade - foi trabalhada a equação da continuidade e como calcular a vazão em circunstancias de vários tubos ligados a caixa dágua de uma casa.

Bomba - as Bombas são máquinas hidráulicas operatrizes que fornecem energia ao liquido com a finalidade de transportá-lo de um ponto a outro.
Além disso, a mesma recebe energia mecânica e a transformam em energia cinética e de pressão ou em ambos.

Energia de Pressão - Pressão é definida como a força por unidade de área. É usualmente mais conveniente usar a pressão ao invés da força para descrever as influências sobre o comportamento de um fluido.

Energia Cinética - A energia que um corpo adquire quando está em movimento chama-se energia cinética. A energia cinética depende de dois fatores: da massa e da velocidade do corpo em movimento.

Número de Reynolds - relaciona as forças inerciais e as forças de viscosidade da vazão de um determinado fluido.

\section{Conclusões}

O uso de experimentação promove o interesse do aluno sobre o tema teórico, onde o professor pode potencializar sua capacidade didática através do seu conhecimento especifico e buscar formas alternativas de obter melhores resultados no processo de aprendizagem do aluno, essa experiência mostra que é muito bem vindo ao meio universitário a experimentação no ensino.

\section{Agradecimentos}

Agradeço a instituição Unicamp pela oportunidade de aprendizagem tecnológica, as monitoras e a professora orientadora Lubienska Cristina Lucas Jaquiê Ribeiro, por nos fornecer tudo que era necessário para o entendimento das práticas de laboratório.

\footnotetext{
${ }^{1}$ Neto, J. M. A.; Alvarez, G. A. Manual de Hidráulica. Edgard Blucher Ltda. São Paulo. $8^{\mathrm{a}}$ edição. 1998. 669 pp.
} 